\title{
VAGINAL GLYCOGEN ASSAY FOR OESTROGEN: SPECIFICITY AND APPLICATION TO BLOOD AND URINE
}

\author{
T. R. WRENN, JOAN R. WOOD, JOEL BITMAN AND \\ T. H. BRINSFIELD \\ U.S. Department of Agriculture, Animal Husbandry Research Division, \\ Agricultural Research Center, Beltsville, Maryland 20705, U.S.A.
}

(Received 5th December 1967)

\begin{abstract}
Summary. A new micro-bio-assay method involving the increase of vaginal glycogen in response to local administration has been used to determine the oestrogenic content of urine and blood. In addition, various other steroid hormones (progesterone, cortisol, desoxycorticosterone, testosterone) were given to test the specificity of the assay. In no instance did the other hormones elicit a glycogen response when given alone, nor did they enhance the response when given in combination with oestrogen.
\end{abstract}

In a previous report from this laboratory (Wrenn, Bitman \& Wood, 1968), the rapid increase in vaginal glycogen caused by local administration of oestrogens to adolescent, ovariectomized rats has been characterized, and suggested as being suitable for the determination of the oestrogenic content of biological materials. The method was shown to be sensitive to small doses, with as little as $2.5 \times 10^{-5} \mu \mathrm{g}$ oestradiol being detected. This paper deals with the assay of biological fluids and the specificity of the reaction.

The assay was conducted by instilling $0.01 \mathrm{ml}$ of solution into the vaginae of 49 to 51-day-old adolescent rats which had been ovariectomized 10 to 12 days previously. The rats were killed $5 \mathrm{hr}$ after the injection and the vaginae excised as described earlier (Wrenn et al., 1968). Glycogen determinations were made by the anthrone method of Seifter, Dayton, Novic \& Muntwyler (1950).

We have applied the assay to the determination of the oestrogenic content of a limited number of urine and blood samples. Table 1 shows the variety of materials assayed and the estimate of their potency. No activity was detected in human male and post-menopausal urines when they were instilled into the vagina in the undiluted condition. Samples of human pregnancy urine near term had the equivalent of about $2 \mu \mathrm{g}$ oestradiol $-17 \beta / \mathrm{ml}$ of urine. It was necessary to dilute this urine 400 times with distilled water in order to get it within the limits of potency detectable by the assay. The oestrogenic potency of untreated and unconcentrated pregnant cow urine was low-only about $6 \%$ of the usual urinary excretion values reported by Velle (1958). 
Both human and cow pregnancy urine were hydrolysed in an attempt to determine conjugated as well as free oestrogen in urine. The method involved hydrolysis with hydrochloric acid followed by ether extraction (four times). The samples were dried, then dissolved in ethyl alcohol and sufficient water dilution made to get the sample within the measurable range. The estimates for the hydrolysed urines (Table 1) agree well with published ranges of oestrogenic potency of urine determined by other methods (Mellin \& Erb, 1965; Zarrow, Yochim \& McGarthy, 1964).

Circulating oestrogen was determined in the blood of a limited number of cows either cycling or during very early pregnancy. Table 2 shows the results

TABLE 1

OESTRADIOL-17 $\beta$ EQUIVALENTS IN URINES

\begin{tabular}{l|l}
\hline & $\mu g / m l$ \\
\hline Untreated, unconcentrated & \\
Human male & 0 \\
Post-menopausal & 0 \\
Human pregnancy (9th month) & $2 \cdot 0$ \\
Non-pregnant cow & $0 \cdot 005$ \\
Pregnant cow (9th month) & 0.05 \\
\hline Acid hydrolysed & \\
Human pregnancy (8th month) & 14.8 \\
Human pregnancy (9th month) & 10.3 \\
Pregnant cow (9th month) & 1.7 \\
\hline
\end{tabular}

TABLE 2

OESTRADIOL- $17 \beta$ EQUIVALENTS IN HYDROLYSED COW PLASMA

\begin{tabular}{c|cc}
\hline Time & \multicolumn{2}{|c}{$\mu g \times 10^{-5}$ per ml } \\
& Cycling & Pregnant \\
\hline Oestrus & $10(1)$ & $26(4)$ \\
Day 7 & $6(1)$ & $5(1)$ \\
Day 14 & $3(2)$ & $30(1)$ \\
\hline
\end{tabular}

Parentheses denote no. of cows.

of these observations. Fifty-millilitre samples of plasma were extracted with ether to obtain free oestrogens, and then hydrolysed successively with enzyme and with acid. The combined ether extracts were then purified to remove neutral steroids and pigments. Our finding of about $20 \times 10^{-5} \mu \mathrm{g}$ oestradiol-17 $\beta$ equivalents/ml during oestrus is much more than the activity reported by Pope, Jones \& Waynforth (1965). They used Martin's tetrazolium method of assay and found amounts totalling 1 to $10 \times 10^{-6} \mu \mathrm{g} / \mathrm{ml}$ expressed as oestrone.

The specificity of the vaginal glycogen assay for oestrogen was studied by comparing the effects of oestradiol-17 $\beta$ with other substances administered intravaginally. Progesterone, cortisol, desoxycorticosterone, testosterone and diethylstilboestrol, both alone and in combination with oestradiol-17 $\beta$, were 


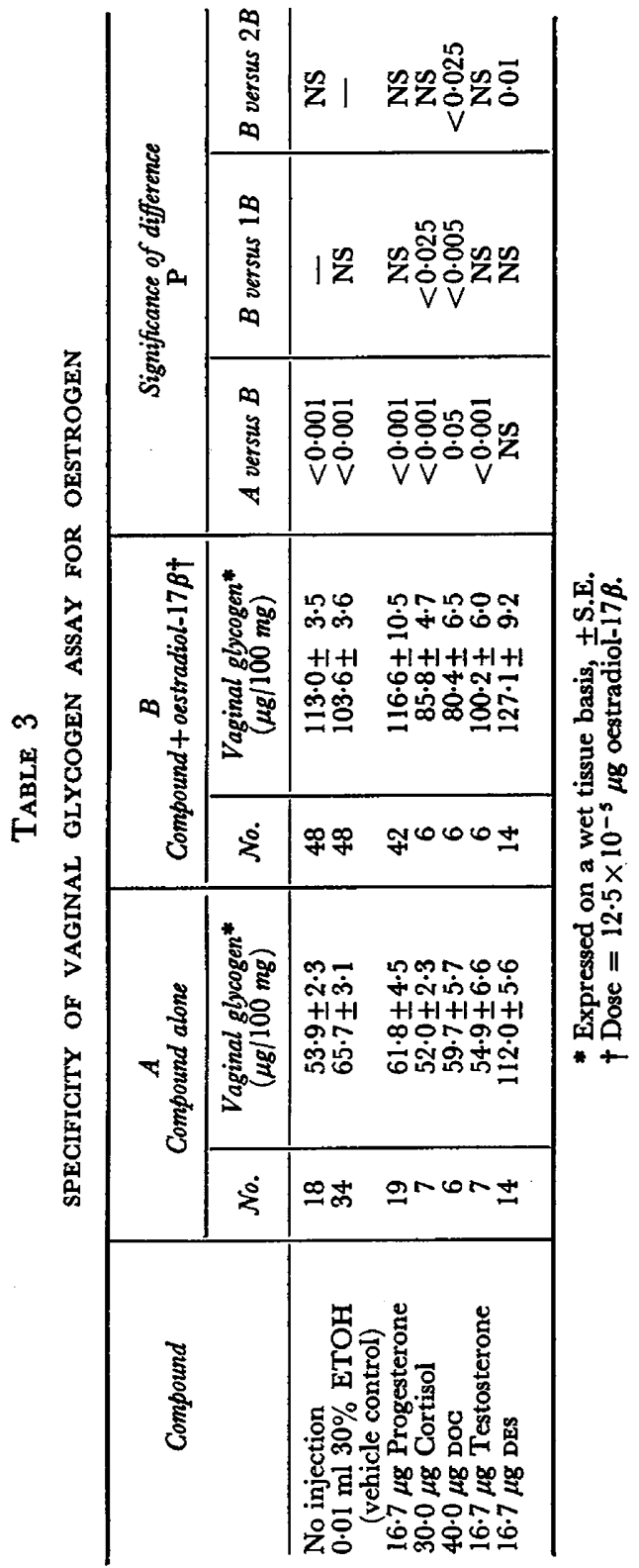


assayed. Since these preparations were administered in solution in $0.01 \mathrm{ml}$ of $30 \%$ ethyl alcohol, appropriate alcoholic control instillations were also made.

Table 3 shows the results of these specificity experiments. Progesterone, cortisol, desoxycorticosterone and testosterone did not elicit a vaginal glycogen response. Progesterone or testosterone when given in combination with oestradiol-17 $\beta$ was ineffective in antagonizing the glycogenic action of oestradiol-17 $\beta$, but the cortical hormones, cortisol and Doc, produced a slight repression of the response. Diethylstilboestrol (DES), the synthetic oestrogen, stimulated increases in vaginal glycogen, and a significantly greater response was observed when it was given with oestradiol-17 $\beta$ than when given with the vehicle control.

TABLE 4

VAGINAL GLYCOGEN RESPONSE WITH VARIOUS OESTROGENS

\begin{tabular}{|c|c|c|c|}
\hline Oestrogen & $\begin{array}{c}\text { Dose } \\
\left(\mu g \times 10^{-5}\right)\end{array}$ & No. & $\mu g / 100 \mathrm{mg}$ wet vagina* \\
\hline Oestradiol-17 $\beta$ & $\begin{array}{r}2 \cdot 5 \\
12 \cdot 5\end{array}$ & $\begin{array}{l}89 \\
72\end{array}$ & $\begin{array}{r}90 \cdot 4 \pm 2 \cdot 7 \\
114 \cdot 8 \pm 3 \cdot 3\end{array}$ \\
\hline Oestradiol-17 $\alpha$ & $\begin{array}{r}25 \cdot 0 \\
125 \cdot 0\end{array}$ & $\begin{array}{l}5 \\
3\end{array}$ & $\begin{array}{l}63 \cdot 1 \pm 6 \cdot 5 \\
68 \cdot 1 \pm 3 \cdot 9\end{array}$ \\
\hline Oestrone & $\begin{array}{l}50 \cdot 0 \\
75 \cdot 0\end{array}$ & $\begin{array}{l}26 \\
18\end{array}$ & $\begin{array}{r}80 \cdot 5 \pm 3 \cdot 8 \\
100 \cdot 9 \pm 7 \cdot 3\end{array}$ \\
\hline Oestriol & $\begin{array}{r}5 \cdot 0 \\
10 \cdot 0\end{array}$ & $\begin{array}{l}35 \\
31\end{array}$ & $\begin{array}{l}83 \cdot 5 \pm 4 \cdot 6 \\
96 \cdot 6 \pm 5 \cdot 1\end{array}$ \\
\hline
\end{tabular}

* Mean \pm S.E.

A comparison was made of the ability of the three natural oestrogens to stimulate increases in vaginal glycogen. Table 4 shows the results for two dose levels of each oestrogen. We found oestriol to be as potent as oestradiol but oestrone was only about one-tenth as active. Oestradiol-17 $\alpha$ was inactive at the $10^{-3} \mu \mathrm{g}$ dose level.

\section{REFERENCES}

Melin, T. N. \& ERB, R. E. (1965) Estrogens in the bovine-A review. F. Dairy Sci. 48, 687.

Pope, G. S., Jones, H. E. H. \& Waynporth, H. B. (1965) Oestrogens in the blood of the cow. $\mathcal{F}$. Endocr. 33, 385.

Seifter, S., Dayton, S., Novic, B. \& Muntwyler, E. (1950) The estimation of glycogen with the anthrone reagent. Archs Biochem. 25, 191.

VeLLE, W. (1958) Undersokelser over naturlig forekommende Østrogener hos droutyggere og gris. Institutt for Seksualfysiologi og Seksualpatologi, Norges veterinaerhøgskole, Oslo, Norway.

WRENN, T. R., BitMan, J. \& WOOD, J. R. (1968) Influence of local estrogen administration on vaginal glycogen. Endocrinology, 82, 62.

Zarrow, M. X., Yochim, J. M. \& McGarthy, J. L. (1964) Experimental endocrinology. Academic Press, New York. 